BBA 12167

\title{
STAKCH-GEL ELECTROPHORESIS OF CITRATE-CONDENSING ENZYME FROM PIG HEART
}

\author{
I. BRODER AND PAUL A. SRERE
}

Departments of Biologicai Chemistry ond Internal Medicine. The Universily of Miehigan, Ann Arbor, Mich. (U.S.A.)

(Received August 24th, rg62)

\section{SUMMARY}

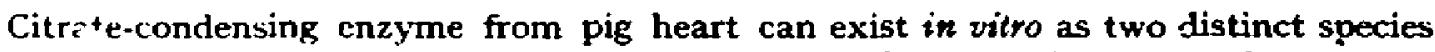
which arc separable by sterch-gel electrophoresis. Several mild types of treatment can interconvert these enzymes and suggest that the separate forms arise in the process of purification; the two enzymes may differ only in the state of reduction of their sulfhydryl groups.

\section{IXTKODUCTION}

Crystalline citrate-condensing enzyme from pig heart has been shown to be a homogeneous protein by ultracentrifugal and electrinhoretic techniques... In our recent work with this protein we have applied immunological and starch-gel electrophoretic methods to the study of its homogeneity. Although immunochemical studies gave no information on this question, the results reported in this paper indicate that pig-heart citrate-condensing enzyme can exist in two closely related forms that are distinguistrable by starch-gel clectrophoresis.

\section{METHODS AND MATERIALS}

Citrate-condensing enzyme was prepared from pig heart and its enzymic activity assayed spectruphotometrically at $340 \mathrm{~m} \mu$ using the coupled malate dehydrogenase system ${ }^{2}$. Boehringer malate dehydrogenase and CoA were used and acetyl-CoA was prenared by the method of Simon AND Shemint. Protein was determined by the method of Lowry et al.5. Enzyme solutions were ultracentrifuged in a Spinco Model E Citracentrifuge at $59680 \mathrm{rev}$./min. Chromatography on DEAE-cellulose was carried out as described previously" using either a stepwise elution or a gradient elution method.

Zone electrophoresis in starch gel was carried out at $4^{\circ}$ and at $\mathrm{pH} 8.6$ using $0.08 \mathrm{M}$ Tris-citrate in the gels and $0.3 \mathrm{M}$ sodium borate in the electrode chamberst. ${ }^{t}$. The fel molds measured $17.5 \mathrm{~cm} \times 1.8 \mathrm{~cm} \times 0.6 \mathrm{~cm}$. The enzyme sample (80-120 units/ $\mathrm{ml}$ ) was dialyzed against the Tris-citrate buffer and $0.05-0.1 \mathrm{ml}$ applied to a piece of Whatman No. I7 chromatography pape: for insertion into the gel. A potential difference of approx. $4.5 \mathrm{~V} / \mathrm{cm}$ was applied to the gels and electrophoresis allowed to 
proceed for 14-16 h. The gels were then cut ho:izontaily and the top tacif staiticu with a saturated amido black solution; the bot $\neq 0 m$ half was sliced into $25-30$ sections with a special cutting apparatus which cnabled reproducible cutting of sections as short as $0.25 \mathrm{~cm}$. Each section was placed in a tube and stored at $-20^{\circ}$.

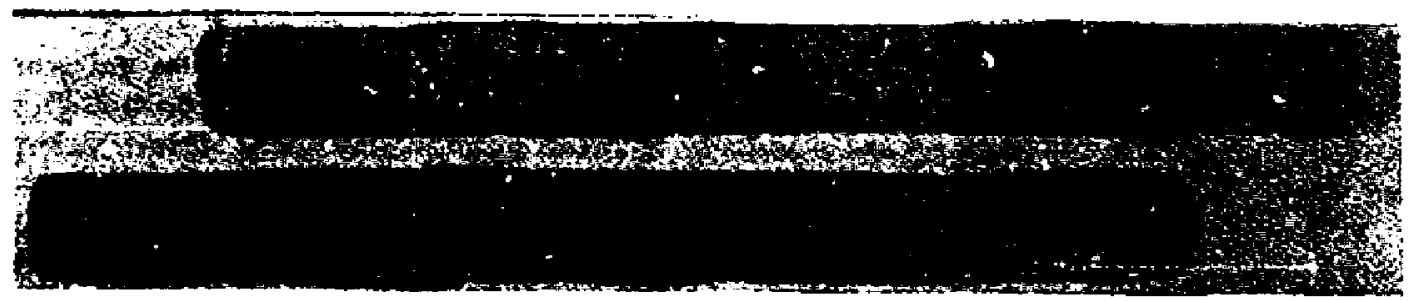

Fig. I. Starch gels stained for proteln, following electrophoresis of two separate preparations of three times recrystallized citrats-condensiig enzyme.

The fractions were thawed and eluted by crushing the gel in $0.08 \mathrm{M}$ Tris-citrate buffer ( $\mathrm{pH} 8.6$ ); $0.5 \mathrm{ml}$ of buffer was added for each $0.25 \mathrm{~cm}$ length of gel. Enzyne activity was measured on an aliquot of the supernatant solution. A $60-05 \%$ recovery of the initial enzymic activity was usually obtained. Electrophoresis with different buffer systems at other $\mathrm{pH}$ values gave porer resolution. The enzyme migrated towards the positive electrode.

\section{RESULTS}

Fig. I shows the protein-stained starch gels from two separate preparations of three times recrystallized citrate-condensing enzyme. The lower gel shows two bands that

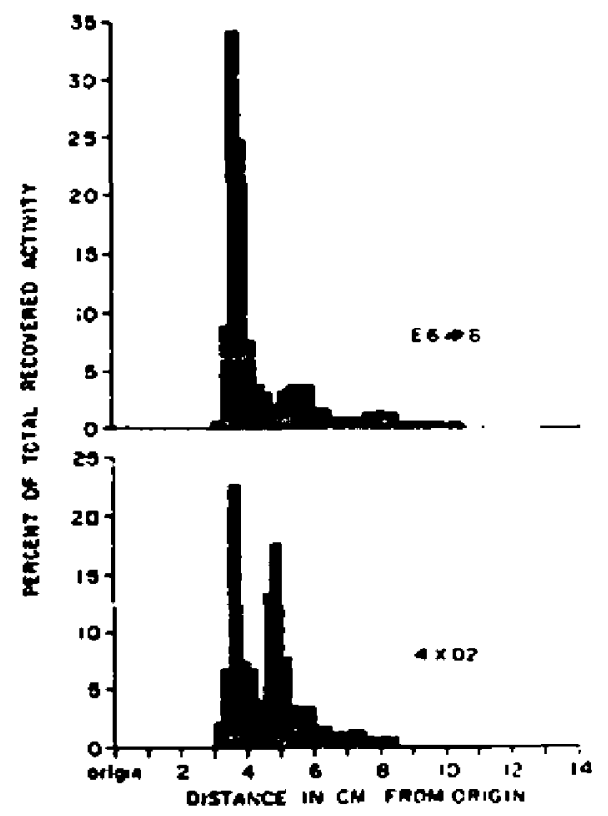

Fig. 2. Enzyme elution patles vis vistained from gels shoun in Fig. r. The relative positions of the bandg atrining fin prontein are marked in crms-batching along the borizontal ordinate. 
stain as protein. Only ane of these bands can be seen in the photograph of the upper gel. The original specimen of the upper gel, however, showed a second faint band corresponding to the second band of the lower gel. The enzyme elution pattems obtained from these gels (Fig. 2) show that each of these bands corresponds to a separate peak of enzyme activity. In the upper gel, there is a small peak of activity which corresponds to the faintly stained band.

T] e specific activities of both forms of the enzyme eluted from the gel were approximately equai. Both electrophoretic forms had identical immunological specificity* When immune serum was fully titrated against one form, there was no residual capacity to react subsequently with the second.

Analytical ultracentrifugation was carried out on a twice recrystallized preparation which on electrophoresis demonstrated two distinct activity peaks. $4^{00}$ units of enzyme ( $x 3 \mathrm{mg}$ ) in $0.7 \mathrm{ml}$ of $0.3 \mathrm{M}$ sodium borate ( $\mathrm{pH} \mathrm{8.6)}$ were centrifuged at $59680 \mathrm{rev} / \mathrm{min}$ and $20^{\circ}$ for $1.5 \mathrm{~h}$. At 38,52 and $86 \mathrm{~min}$ (Fig. 3) a single peak with minimal asymmetry xas seen.

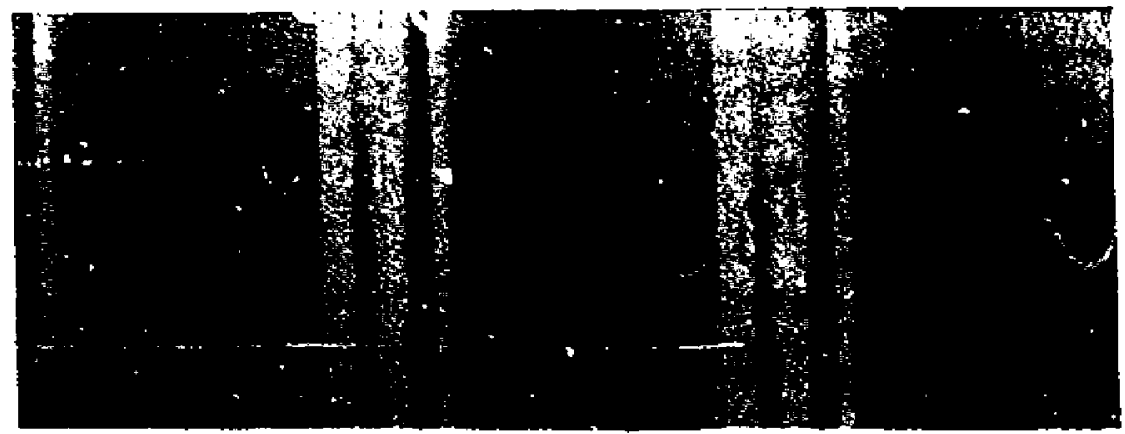

Fig. 3. The sedimentation pattern at 38,52 and $8 \dot{6}$ min of a twice recrystallized enxyme preparation which on starch-gel clectrophoresis showed 2 distinct reglons of enzyme activity.

The gel sections containing cach of the two enzymes were separately inserted into new gels for re-electrophoresis (Fig. 4). Each form yielded only a single band of enzyme activity with the same mobility as the original.

Enzyme solutions were obtained at five successive steps durir.g the purification of citrate-condensing enzymez: (a) original extract of pig heart, (b) protein soluble in a $50 \%$ ammonium sulfate solution, (c) protein that was precipitated in a $70 \%$ ammonium sulfate solution $(50-70 \%$ ammonium sulfate), (d) protein thai was adsorbed and eluted from DEAE-cellulose, (e) crystalline enzyme obtained from ammonium sulfate colutions. It was neressery to concentrate the solutions obtained at steps $a$ and $b$ so that sufficient enzyme activity could be placed on the gel for analysis. We failed to obtain clear resolution of protein or of enzyme activity from these solutions because of their high protein concentrations.

Three preparations of the $50-70 \%$ ammonium sulfate precipitate (step c) showed 2 citrate-condersing enzymes and three others showed only a single enzyme. In those preparations showing a single enzyn: $:$, its migration rate corresprnded to the more rapidly migrating form of those wit: 2 enzymes. When a preparation with two enzymes was re-dialvzed and arain studied by starch-gei electrophoresis, the 


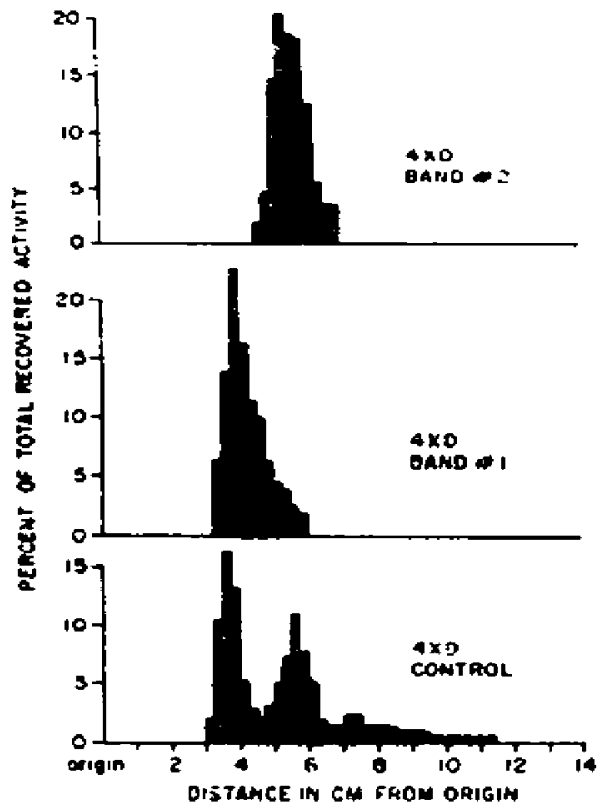

Fig. 4. Frzyme elution patterns obtained from the iadividual enzyme bands which ivere cxciscl from their original $\mathrm{g} \cdot \mathbf{l}$ and re-clect-ophoresed separately. 'l'he lower pattern is from a sample of the original preparation and was run concurrently.

more slowly migrating cnzy'me was gieatly diminished or absent with a corrcsponding inrrease in the rapid enzyme (Fig. 5 ): there was no toss of total activity. This behavior appeaced to be caused by the prolonged ditlysis rather thai altered buffer composition, for when a prepan ation altered by re-dialysis was further dialyzed against the original buffer, the s]ower migrating enzyme was not restored. However. preparations at this state of purification which had always shown oniy the more rapidly migrating enzyme had not been dialyzed longer than the others.

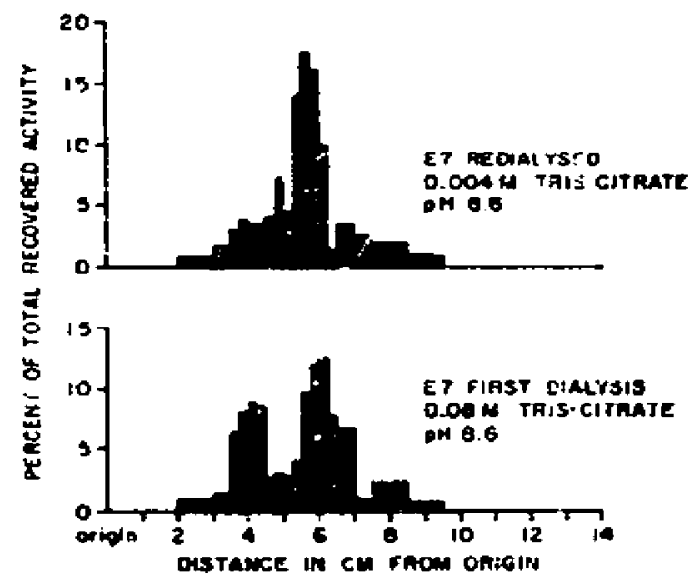

Fig. 5. Enzyme elution patletas of an cuzyne proparatiun at the eed of step c. The lower pattern was obtuined after the initial dialysis and tie uppet ont after a sccond diatysis. 
Chromatography on DEAF-cellulose caused conversion of the faster to the sloser migrating electrophoretic form of enzyme (Fig. 6). In 2 other experiments of this type, almost all of the enzyme was converted to the slowly movirg form, priss to chromatography one of these showed 2 peaks and the other only a single rapidly migrating one. Since the recovery of enzyme from the DEAE-cellulose in these

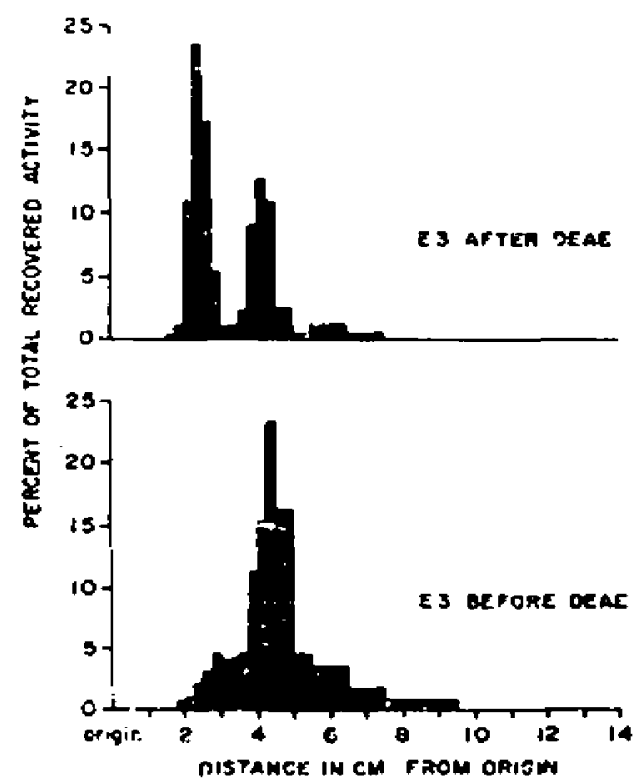

Fib. 6. Enaymu elution patterns on an cnxyme preparation before and after step d.

cxperiments was approx. $80 \%$, it is not possibie to explain the alteration in the amounts of the 2 enzymes on the basis of loss of one form. The enzyme was concentrated for rlectrophoresis either by vacuum evaporation at $30^{\circ}$ or adsorption on calcium plusphate gel and elution in a small volume of $50 \%$ ammonium sulphate

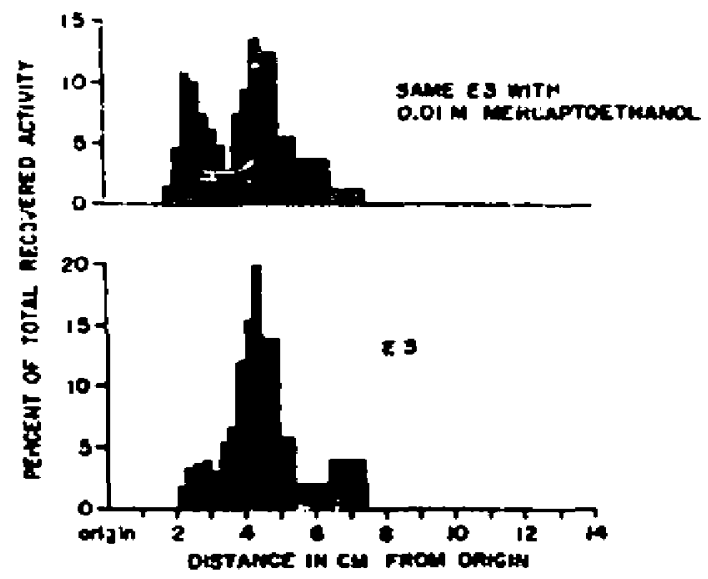

Fig. 7. Enzyme elution patterns of an enzyme preparation before and after treatment witt: mercaptcethanol. 
The electrophoretic behavice was sinilar after botis concentrating procedures. The electrophoretic behavior following chromatography was not influenced by the presencr of the vacuum-concentratued eluates which contained protein but no enzyme; it is unlikely therefore that some other protein influenced the electrophoretic behaviur of the enzyme.

Three preparations were followed through f rectwallization stegs and sisowed

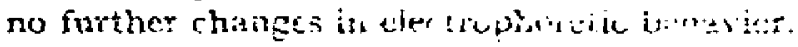

Further stadie; were carried aut on the preparations which had been purifted to the end of the third step. When one of these which had always shown only a single rapidly migrating enzyme was placed in o.or $\mathbf{M}$ mercaptoethanol, subsequent electrophoresis showed that the slower migrating enzyme had been formed (Fig. 7). In preparations with the 2 enzyme ferms in which the slower one decreased after dialysis, a restoration of the slower enzyme could be accomplished with mercaptoethanol.

\section{DISCUSSION}

The presence of multiple protein forms for a single enzyme activity in a single tissuc is well established. Fussible explanations for such multiple enzyme forms are: (a) the proteins may be totally different, (b) one or both of the proteins may have multiple activities, (c) the proteins may be interconvertible, i.e. one is a slight cherrica! modification of the other.

The results obtained by us indicate that the citrate-condensing enzyme from pig heart can exist in two closely related forms. Several mild types of treatinent can interconvert these enzymes, suggesting that the separate forms may arise in the process of purification. There are several enzymes ${ }^{3} 12$ which seem to be similar to tije condensing enzyme in this respect.

It is unlikely that the two vnzymes represent two different states of assoriation since only a single peak is seen upon ultracentrifugation.

Citrate-condensing enzyme contains $2-3$ moles of sulfhydryl groups that are not essential for its activity ${ }^{3}$. The action of mercaptoethanol in causing the change of one form to the other. suggests that the modification involves an SH to SS conversion. The slowly migrating form would then be $\mathrm{SH}$ enzyme and the more ra $\mathrm{r}_{\mathrm{r}}:$ : moving form the disulfide enzyme; dialysis would lead to the oxidation of $\mathrm{SH}$ groups to SS and cbromatography on DEAE-cellulose would cause a change from the SS enzyine to the reduced enzyme. Such a conversion on DEAE-cellulose is not expected, but cannot be excluded.

The findings do not eliminate the possibility that citrate-condensing enzinte may exist as more than a single molecular species in living pig-heart tissue.

\section{ACKNOWLEUGEME:TS}

This work was supported by a grant of the United States Public Health Service (H-5328).

The first Autbor is a R. Samuel McLaughlun Travelling Fellow in Medicine, University of Toronto (Canada). 


\section{- REFERENCES}

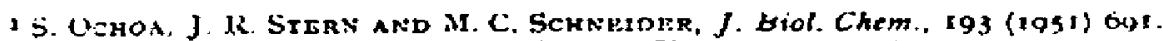

$=$ P. A. SRFRE AND G. W. IKOSICKI, J. Biol. Cheni, 236 (rght) 2557.

- I. Broper and P. A. SRtre, Biorhim. Biophys. Acta, 67 (1963) 657)

- E. J StMoN aNd D. SHIMJN, J. Am. Chem. Soc. 75 (1953) 2520.

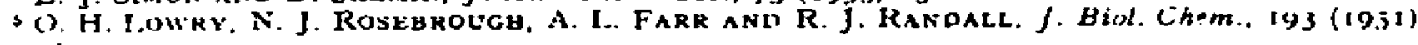
2155

- O. S4tтнurs, Biochem. J., 6 (1955) 629

M. D. Pojtik. J. Immunot. 82 (1950) 502.

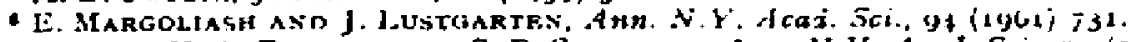

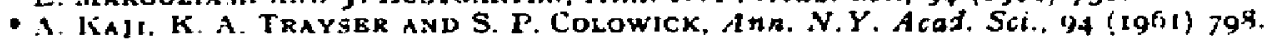

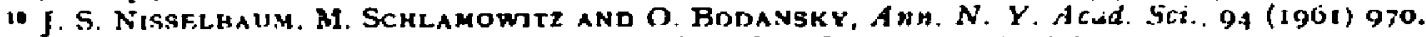

12 R. Shaplika axd S. Parker, Biocherh. Biophys. Res. Commun., 3 (19tio) 200.

12 1. J. Sophtakopotitos hivo C. S. Festlenc. Biochim. Biophys. Atha. 45 (1965) 400. 